\title{
REVIEW
}

\section{Nitrate uptake, nitrite release and uptake, and new production estimates}

\author{
Yves Collos* \\ Laboratoire d'Hydrobiologie (UMR CNRS 5556), Université Montpellier II, CC093, F-34095 Montpellier CEDEX 5, France
}

\begin{abstract}
Excretion of nitrite during nitrate assimilation by phytoplankton is examined in relation to estimates of new production. Evidence from the literature indicates that nitrite excretion is exhibited by a wide variety of phytoplankton species in cultures and can represent up to 25,45 and $50 \%$ of nitrate uptake in Thalassiosira pseudonana, Prorocentrum minimum and Skeletonema costatum respectively, at irradiance levels which are typical of the primary nitrite maximum in oligotrophic oceans. In natural populations, nitrite excretion can represent up to $60 \%$ of nitrate uptake in surface waters of upwelling areas. Conversely, nitrite uptake can equal or exceed nitrate uptake in several species of marine phytoplankton in cultures as well as in natural populations. The first phenomenon can lead to large: ariations of the net/gross new production estimates, as well as widely biased estimates of the $f$ ratio. For example, a nitrite excretion of $40 \%$ of nitrate uptake will lead to a $33 \%$ underestimate of the $f$ ratio in a range of values typical of oligotrophic oceans. The effects of nitrite uptake taking place concurrontly with nitrate uptake are more difficult to assess, but the overall result is that $f$ ratios in stratified oceanic areas are probably underestimated by the ${ }^{15} \mathrm{~N}$ tracer technique
\end{abstract}

KEY WORDS: Nitrite - Excretion Uptake New production

\section{INTRODUCTION}

The present work was inspired by the review of Platt et al. (1989) in which a parallel is established between primary production in terms of carbon and nitrogen. Briefly stated, Platt et al. (1989) argue that net primary production in terms of carbon is equivalent to total production in terms of nitrogen (new plus regenerated production sensu Dugdale \& Goering 1967). In support of this argument, the authors point out that 'there is no evidence that phytoplankton remineralise nitrogen'. They add that 'the distinction (between equating nitrogen production with either gross or net carbon production) is of significance for calculations involving the interconversion of carbon and nitrogen'. While the second point is beyond dispute, recent work on the nitrogen cycle (Bronk et al. 1994, Slawyk \& Raimbault 1995, Collos et al. 1996) has revealed that phenomena such as dissolved organic nitrogen excretion do affect

•E-mail: collos@univ-montp2.fr estimates of both new and regenerated production in a significant way. In the present review, I examine another aspect of this problem, which is the release of nitrite during uptake of nitrate by unicellular algae in laboratory cultures as well as by natural marine phytoplankton.

\section{UNICELLULAR ALGAE AS ION EXCHANGERS}

Unicellular algae are much more prone to large exchanges of nitrogen with the surrounding environment than higher plants for 2 reasons. The first one is the high surface/volume ratio which makes them more liable to exchange material with the external medium, and the second reason is their low carbon/nitrogen composition ratio relative to higher plants. For example, carbon/nitrogen ratios for unicellular algae range from 5 to 20 (Caperon \& Meyer 1972, Laws \& Wong 1978) and for higher plants from 18 to 120 (Epstein 1972, Newell et al. 1984), giving more importance to nitrogen 
compounds in their overall metabolism. During assimilation of nitrate for example, they can accumulate several intermediate compounds during the reduction pathway, ultimately leading to protein synthesis (Collos \& Slawyk 1980, Dortch et al. 1984). This accumulation inevitably leads to the establishment of concentration gradients and diffusion or leakage of material to the outside. However, in the case of nitrite, internal pools are generally undetectable in phytoplankton cells (Thoresen et al. 1982, Dortch et al. 1984). When detected, internal nitrite was usually found in very limited quantities (Eppley \& Coatsworth 1968, Conover 1975), but there are exceptions (Flynn \& Flynn 1998). In spite of this, nitrite release appears to be widespread in marine microalgae. However, the mechanism of nitrite release is not clear. I have tried to assess the relative importance of active excretion versus passive diffusion following Bjørnsen (1988) using literature data. Table 1 shows the results of linear regressions between nitrite release rates (per unit volume culture) and either microalgal biomass (cells $\mathrm{l}^{-1}$ ) or nitrate uptake rate (per liter of culture). The results are rather inconclusive as, in 2 out of 3 cases, the relationship between nitrite release and biomass was highly significant, indicating that diffusion processes were more important than active excretion, while the third study indicated the opposite. In this review, nitrite release will generally be considered as an active process depending on nitrate uptake. Net nitrate uptake is defined as the rate estimated from ${ }^{15} \mathrm{~N}$ incorporation in phytoplankton cells and is compatible with the definition of Bronk et al. (1994). However, in the present case, gross nitrate uptake is the sum of net nitrate uptake and nitrite excretion. Other phenomena such as cell lysis or animal feeding on phytoplankton which also lead to production of extracellular products will not be examined here.

\section{NITRITE EXCRETION DURING NITRATE UPTAKE}

In laboratory cultures (Table 2), the values of nitrite excretion as a percentage of nitrate uptake range between zero and $50 \%$ in the light and between zero and $96 \%$ in the dark. No particular interspecific trends could be established. The high variability in values obtained by different investigators on the same species (e.g. Skeletonema costatum) may be due to several factors. Early work carried out on batch cultures followed concentration changes over relatively long periods of time and slow changes in nutritional conditions. More recent work with continuous cultures has allowed the study of rather abrupt changes in nutrient levels by imposing nutrient spikes, leading to perturbations of the assimilatory pathways and subsequent release of intermediate compounds. Those perturbations of the nutrient regime are thought to be representative of natural phenomena such as nitrate intrusions into the euphotic zone of stratified oceanic areas (Dugdale 1977, Klein \& Coste 1984, Holligan et al. 1985). Higher sampling rates in more recent studies could also have contributed to revealing phenomena of a greater amplitude than previously reported.

Nitrite excretion has been found to be greater in the dark than in the light for several species of marine microalgae (Vaccaro \& Ryther 1960, Laws \& Wong 1978. Collos 1982, Raimbault 1986). ZoBell (1935) noted that 'the concentration of nitrite is usually greatest early in the morning and diminishes with exposure to light' in batch cultures of marine diatoms. This can be explained by the light requirements of nitrite reductase. Ferredoxin, which is the electron donor for this enzyme, is synthesized during photosynthesis only (Losada et al. 1981).

Nitrite excretion by unicellular algae may be highly dependent on the growth rate in the dark period but not in the light period (Laws \& Wong 1978). There are also large intergeneric differences at this level. For example, nitrite excretion was growth rate dependent in the light period for Prorocentrum minimum (Sciandra \& Amara 1994), but not for Pavlova lutheri (Laws \& Wong 1978). Nitrite excretion has been shown to depend on temperature (Mihnea \& Voinescu 1979, Raimbault 1986), the external nitrate concentration (Serra et al. 1978,

Table 1. Relationship between nitrite release, biomass and nitrate uptake in laboratory cultures of marine phytoplankton, according to the linear model $E_{\mathrm{NO}_{2}}=a X+b$, with $X$ elther biomass (cells l-1) or nitrate uptake $\left(U_{\mathrm{NO}_{-}}\right)$. E: excretion; $U:$ uptake $r^{2}$ coefficient of determination; $n$ : number of samples

\begin{tabular}{|c|c|c|c|c|c|}
\hline Species & $x$ & $r^{2}$ & $n$ & $\mathrm{p}$ & Source \\
\hline Isochrysis $\mathrm{sp}$. & $\begin{array}{l}\text { Cells } \mathrm{I}^{-1} \\
U_{\mathrm{NO}_{3}}\end{array}$ & $\begin{array}{l}0.959 \\
0.216\end{array}$ & $\begin{array}{l}5 \\
5\end{array}$ & $\begin{array}{l}0.0036 \\
0.4303\end{array}$ & Vaccaro \& Ryther (1960) \\
\hline Skeletonema costatum & $\begin{array}{l}\text { Cells l-1 } \\
U_{\mathrm{NO}_{3}}\end{array}$ & $\begin{array}{l}0.331 \\
0.139\end{array}$ & $\begin{array}{l}28 \\
26\end{array}$ & $\begin{array}{l}0.0014 \\
0.0608\end{array}$ & Carlucci et al. (1970) \\
\hline Thalassiosira pseudonana & $\begin{array}{l}\text { Cells 1-1 } \\
U_{\mathrm{NO}_{3}}\end{array}$ & $\begin{array}{l}0130 \\
0.447\end{array}$ & $\begin{array}{l}18 \\
18\end{array}$ & $\begin{array}{l}0.1417 \\
0.0024\end{array}$ & Kiefer et al. (1976) \\
\hline
\end{tabular}


Table 2. Nitrite excretion during nitrate uptake by laboratory cultures of marine microalgae. E: excretion; U: uptake; N: nitrogen; L: light; D: dark; $\mu$ : growth rate

\begin{tabular}{|c|c|c|c|}
\hline Species & $E_{\mathrm{NO}_{2}} / U_{\mathrm{NO}_{3}}$ & Conditions & Source \\
\hline Alexandrium minutum & $\begin{array}{l}0 \\
1.0 \\
0 \\
0.5-0.6\end{array}$ & $\begin{array}{l}\mathrm{NO}_{3}+\mathrm{NH}_{4} \text { limited, } \mathrm{L} \\
\mathrm{NO}_{3}+\mathrm{NH}_{4} \text { limited, } \mathrm{D} \\
\text { Dark-fed, } \mathrm{L} \\
\text { Dark-fed, } \mathrm{D}\end{array}$ & $\begin{array}{l}\text { Flynn \& Flynn (1988) } \\
\text { Flynn \& Flynn (1988) } \\
\text { Flynn \& Flynn (1988) } \\
\text { Flynn \& Flynn (1988) }\end{array}$ \\
\hline Biddulphia aurita & 0.001 & N starved $48 \mathrm{~h}$ & Lui \& Roels (1972) \\
\hline Chaetoceros affinis & $0.01-0.02$ & $\mathrm{NO}_{3}$ limited, $\mathrm{L}$ & Raimbault (1986) \\
\hline $\begin{array}{l}\text { Chaetoceros curvisetus } \\
\text { Chaetoceros simplex } \\
\text { Chaetoceros simplex }\end{array}$ & $\begin{array}{l}0.08-0.10 \\
0-0.16 \\
0.21-0.29\end{array}$ & $\begin{array}{l}\mathrm{NO}_{2} \text { grown, } \mathrm{L} \\
\mathrm{N} \text { sufficient, } \mathrm{L} \\
\mathrm{N} \text { limited, } \mathrm{L}\end{array}$ & $\begin{array}{l}\text { Anderson \& Roels (1981) } \\
\text { Mihnea \& Voinescu (1979) } \\
\text { Mihnea \& Voinescu (1979) }\end{array}$ \\
\hline Cyclotella caspia & $\begin{array}{l}0.20-0.32 \\
0.17-0.75\end{array}$ & $\begin{array}{l}\mathrm{N} \text { sufficient, } \mathrm{L} \\
\mathrm{N} \text { limited, } \mathrm{L}\end{array}$ & $\begin{array}{l}\text { Mihnea \& Voinescu (1979) } \\
\text { Mihnea \& Voinescu }(1979)\end{array}$ \\
\hline Dunaliella tertiolecta & $\begin{array}{l}0 \\
0.20-0.26\end{array}$ & $\begin{array}{l}\mathrm{NO}_{3} \text { limited, } \mathrm{L} \\
\mathrm{NO}_{3} \text { limited, } \mathrm{D}\end{array}$ & $\begin{array}{l}\text { Laws \& Wong (1978) } \\
\text { Laws \& Wong (1978) }\end{array}$ \\
\hline Isochrysis $\mathrm{sp}$. & $0-0.03$ & $N$ deficient, $\mathrm{L}$ & Vaccaro \& Ryther (1960) \\
\hline Lauderia sp. & $0.01-0.07$ & $N$ deficient, $\mathrm{L}$ & Vaccaro \& Ryther (1960) \\
\hline Pavlova lutheri & $\begin{array}{l}0-0.02 \\
0.95 \\
0.93 \\
0.96 \\
0.32 \\
0\end{array}$ & $\begin{array}{l}\mathrm{NO}_{3} \text { limited, } \mathrm{L} \\
\mu=0.005 \mathrm{~h}^{-1}, \mathrm{D} \\
\mu=0.015 \\
\mu=0.029 \\
\mu=0.043 \\
\mu=0.059\end{array}$ & $\begin{array}{l}\text { Laws \& Wong }(1978) \\
\text { Laws \& Wong }(1978) \\
\text { Laws \& Wong }(1978) \\
\text { Laws \& Wong }(1978) \\
\text { Laws \& Wong }(1978) \\
\text { Laws \& Wong }(1978)\end{array}$ \\
\hline Phaeodactylum tricornutum & $\begin{array}{l}0.02-0.05 \\
0.04-0.05 \\
0.01-0.03 \\
0.31\end{array}$ & $\begin{array}{l}\mathrm{NH}_{4} \text { limited, } \mathrm{L} \\
\mathrm{NO}_{3} \text { limited, } \mathrm{L} \\
\mathrm{NO}_{3} \text { limited, } \mathrm{L} \\
\mathrm{NO}_{3} \text { limited, } \mathrm{D}\end{array}$ & $\begin{array}{l}\text { Collos }(1982) \\
\text { Collos }(1982) \\
\text { Raimbault }(1986) \\
\text { Raimbault (1986) }\end{array}$ \\
\hline Prorocentrum minimum & $0.002-0.45$ & $\begin{array}{l}\mathrm{NO}_{3} \text { limited, } \mathrm{L} \\
\mu \text { dependent }\end{array}$ & $\begin{array}{l}\text { Sciandra \& Amara (1994) } \\
\text { Sciandra \& Amara (1994) }\end{array}$ \\
\hline Scrippsiella trochoidea & $\begin{array}{l}0 \\
0\end{array}$ & $\begin{array}{l}\mathrm{NO}_{3} \text { limited, L, D } \\
\mathrm{NO}_{3}+\mathrm{NH}_{4} \text { limited, L, D }\end{array}$ & $\begin{array}{l}\text { Flynn \& Flynn (1998) } \\
\text { Flynn \& Flynn (1998) }\end{array}$ \\
\hline Skeletonema costatum & $\begin{array}{l}0-0.004 \\
0-0.010 \\
0-0.010 \\
0.005-0.010 \\
0.14-0.17 \\
0.25-0.50 \\
0.02-0.27 \\
0.15-0.30 \\
0.01-0.38 \\
0.10-0.40 \\
0.05 \\
0.25 \\
0.35 \\
0.05\end{array}$ & $\begin{array}{l}\mathrm{N} \text { deficient, } \mathrm{L} \\
\mathrm{N} \text { sufficient, } \mathrm{D} \\
\mathrm{N} \text { sufficient, } \mathrm{L} \\
\mathrm{N} \text { starved } 24 \mathrm{~h}, \mathrm{~L} \\
\mathrm{~N} \text { sufficient, } \mathrm{L} \\
\mathrm{N} \text { deficient, } \mathrm{L} \\
\mathrm{NO}_{3} \text { limited, } \mathrm{L} \\
\mathrm{NO}_{3} \text { limited, } \mathrm{D} \\
\mathrm{NH}_{4} \text { limited, L } \\
\mathrm{NH}_{4} \text { limited, } \mathrm{D} \\
\mathrm{N} \text { starved } 12 \mathrm{~h}, \mathrm{~L} \\
\mathrm{~N} \text { starved } 24 \mathrm{~h} \\
\mathrm{~N} \text { starved } 36 \mathrm{~h} \\
\mathrm{~N} \text { starved } 48 \mathrm{~h}\end{array}$ & $\begin{array}{l}\text { Vaccaro \& Ryther (1960) } \\
\text { Vaccaro \& Ryther (1960) } \\
\text { Carlucci et al. (1970) } \\
\text { Carlucci et al. (1970) } \\
\text { Serra et al. (1978) } \\
\text { Serra et al. (1978) } \\
\text { Collos (1982) } \\
\text { Collos (1982) } \\
\text { Collos (1982) } \\
\text { Collos (1982) } \\
\text { Martinez (1991) } \\
\text { Martinez (1991) } \\
\text { Martinez (1991) } \\
\text { Martinez (1991) }\end{array}$ \\
\hline Thalassiosira allenii & $\begin{array}{l}0.01-0.02 \\
0.04-0.06\end{array}$ & $\begin{array}{l}\mathrm{NO}_{3} \text { limited, } \mathrm{L} \\
\mathrm{NO}_{3} \text { limited, } \mathrm{D}\end{array}$ & $\begin{array}{l}\text { Laws \& Wong }(1978) \\
\text { Laws \& Wong }(1978)\end{array}$ \\
\hline $\begin{array}{l}\text { Thalassiosira pseudonana } \\
\qquad \begin{array}{l}66 \mathrm{~A} \\
13-1 \\
3 \mathrm{H}\end{array}\end{array}$ & $\begin{array}{l}0.03 \\
0.25 \\
0.01-0.07 \\
0 \\
0.03-0.06\end{array}$ & $\begin{array}{l}\mathrm{NO}_{3} \text { sufficient } \\
\mathrm{NO}_{3} \text { limited, } \mathrm{L} \\
\mathrm{NO}_{3} \text { limited. } \mathrm{L} \\
\mathrm{NO}_{3} \text { limited, } \mathrm{L} \\
\mathrm{N} \text { sufficient, } \mathrm{L}\end{array}$ & $\begin{array}{l}\text { Kiefer et al. (1976) } \\
\text { Kiefer et al. }(1976) \\
\text { Olson et al. }(1980) \\
\text { Raimbault }(1986) \\
\text { Sharp et al. (1979) }\end{array}$ \\
\hline
\end{tabular}

Olson et al. 1980, Collos 1982) and the nitrogen deficiency of the cells (Serra et al. 1978, Martinez 1991). The presence of ammonium in the feed medium of continuous cultures also appears to be important in triggering nitrite excretion in some species (Flynn \& Flynn 1998)
Except for the study of Anderson \& Roels (1981), the irradiance level used by most investigators was characteristic of that prevailing in the lower euphotic zone in stratified oceanic areas (between 50 and $100 \mu \mathrm{mol} \mathrm{m} \mathrm{m}^{-2} \mathrm{~s}^{-1}$ ). In this respect, those results obtained in laboratory cultures are particularly 
relevant to natural features such as the primary nitrite maximum (PNM), which is usually associated in these areas with a strong vertical nitrate gradient (Vaccaro 1965, Herbland \& Voituriez 1977), indicating nitrate utilization.

Field data (Table 3) are considerably less numerous, and more difficult to interpret because ammonium oxidation can also be a source of nitrite. The respective importance of both sources has been a matter of controversy (Vaccaro 1965, Wada \& Hattori 1971). However, there now seems to be general agreement on the fact that, in tropical waters, the PNM is due mostly to nitrate reduction and that ammonium oxidation contributes to nitrite only below the PNM in low oxygen waters (Kiefer et al. 1976, Voituriez \& Herbland 1977, Olson et al. 1980, Dore \& Karl 1996). In the North Pacific subtropical gyre, the latter found high nitrite values early in the morning and lower (by about a factor of 2) values in the afternoon in upper water column profiles. Those temporal patterns are very similar to the observations of ZoBell (1935) in laboratory cultures of marine diatoms. In other oceanic areas such as the Subarctic Pacific, Miyasaki et al. (1975) estimate that $48 \%$ of the nitrite produced in the euphotic zone is due to nitrate utilization. In the euphotic zone of oceanic areas, nitrite excretion has been found to depend on nitrate concentration (Wada \& Hattori 1971, Collos \& Slawyk 1983) and light (Wada \& Hattori 1971, Miyasaki et al. 1973, 1975, Olson et al. 1980), which suggests that the process is autotrophic. If the numbers shown in Table 3 can be taken at face value, the range of values of nitrite excretion relative to nitrate uptake $(0.04$ to 0.60$)$ is almost as wide as in the laboratory studies.

Overall, nitrite excretion by phytoplankton will lead to an underestimate of nitrate uptake when measured by the chemical method (nitrate disappearance) if nitrite is not measured separately. It will also underestimate nitrate uptake when measured by the isotopic method such as the ${ }^{15} \mathrm{~N}$ tracer technique ( $\mathrm{N}$ incorporation in the particulate matter) because of tracer loss during incubation. An indication of the errors involved in determination of the widely used $f$ ratio (Eppley \& Peterson 1979) can be seen in Fig. 1. For nitrite excretion values of 40 and $80 \%$ of nitrate uptake, the underestimates range respectively between 2 and $33 \%$ and 4 and $67 \%$. The larger errors are expected to be found in oligotrophic areas at low values of the $f$ ratio.

\section{NITRITE UPTAKE DURING NITRATE UPTAKE}

Subsequent to nitrite excretion in cultures, there is almost invariably uptake of the same compound, usually when nitrate is close to exhaustion. Table 4 summarizes the data available from laboratory studies.

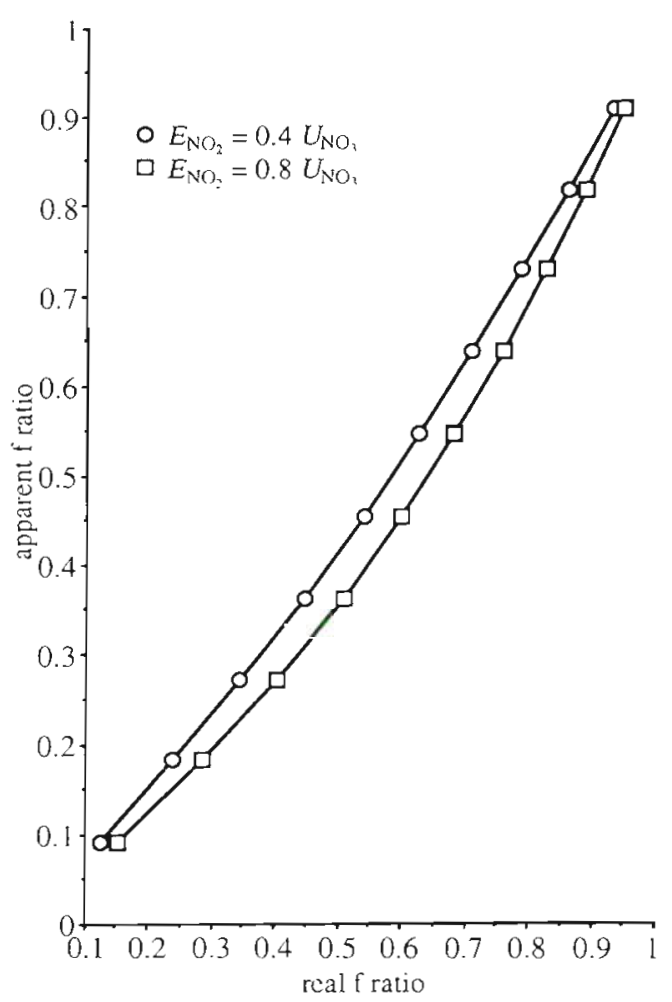

Fig. 1. Influence of nitrte excretion on the $f$ ratio. E: excretion, $U$ : uptake. First, 'apparent' $f$ ratios are computed in the conventional way from a range of net ammonium and nitrate uptake values. Then, nitrite excretion is set at either 40 or $80 \%$ of net nitrate uptake. 'Real' $f$ ratios are then recalculated after adding nitrite excretion to net nitrate uptake and to the sum of net ammonium and nitrate uptake 
Table 4. Nitrate and nitrite uptake following nitrite excretion by laboratory cultures of marine microalgae. U: uptake; L: light; D: dark

\begin{tabular}{|c|c|c|c|}
\hline Species & $U_{\mathrm{NO}_{2}} / U_{\mathrm{NO}_{3}}$ & Conditions & Source \\
\hline Alexandrium minutum & $\begin{array}{l}0.31-0.46 \\
0 \\
0.9-1.0 \\
0\end{array}$ & $\begin{array}{l}\mathrm{NO}_{3}+\mathrm{NH}_{4} \text { limited, } \mathrm{L} \\
\mathrm{NO}_{3}+\mathrm{NH}_{4} \text { limited, } \mathrm{D} \\
\text { Dark fed, L } \\
\text { Dark fed, D }\end{array}$ & $\begin{array}{l}\text { Flynn \& Flynn (1998) } \\
\text { Flynn \& Flynn (1998) } \\
\text { Flynn \& Flynn (1998) } \\
\text { Flynn \& Flynn (1998) }\end{array}$ \\
\hline Biddulphia aurita & $0.0003-0.04$ & $\mathrm{~N}$ starved $48 \mathrm{~h}$ & Lui \& Roels (1972) \\
\hline $\begin{array}{l}\text { Chaetoceros curvisetus } \\
\text { Chaetoceros simplex } \\
\text { Chaetoceros simplex }\end{array}$ & $\begin{array}{l}0.1-1.0 \\
1.3 \\
0.1-1.8\end{array}$ & $\begin{array}{l}\mathrm{NO}_{2} \text { grown, } \mathrm{L}, \mathrm{NO}_{3} \text { added } \\
\mathrm{N} \text { sufficient } \\
\mathrm{N} \text { limited }\end{array}$ & $\begin{array}{l}\text { Anderson \& Roels (1981) } \\
\text { Mihnea \& Voinescu (1979) } \\
\text { Mihnea \& Voinescu (1979) }\end{array}$ \\
\hline Cyclotella caspia & $1.0-2.9$ & N limited & Mihnea \& Voinescu (1979) \\
\hline Isochrysis sp. & 0.50 & N deficient, L & Vaccaro \& Ryther $(1960)$ \\
\hline Lauderia sp. & 0.07 & N deficient, $L$ & Vaccaro \& Ryther (1960) \\
\hline Phaeodactylum tricornutum & $\begin{array}{l}0.1-0.2 \\
0.6 \\
1.3\end{array}$ & $\begin{array}{l}\mathrm{N} \text { starved } 3 \mathrm{~h} \\
\mathrm{NH}_{4} \text { limited, } \mathrm{L} \\
\mathrm{NO}_{3} \text { limited, } \mathrm{L}\end{array}$ & $\begin{array}{l}\text { Cresswell \& Syrett (1982) } \\
\text { Collos }(1982) \\
\text { Collos }(1982)\end{array}$ \\
\hline Prorocentrum minimum & $0.1-10.0$ & $\begin{array}{l}\mathrm{NO}_{3} \text { limited, } \mathrm{L} \\
\mu \text { dependent }\end{array}$ & $\begin{array}{l}\text { Sciandra \& Amara (1994) } \\
\text { Sciandra \& Amara (1994) }\end{array}$ \\
\hline Skeletonema costatum & $\begin{array}{l}0.004-0.013 \\
0.004-0.010 \\
1.7 \\
1.1\end{array}$ & $\begin{array}{l}\mathrm{N} \text { sufficient, } \mathrm{L} \\
\mathrm{N} \text { starved, } \mathrm{L} \\
\mathrm{NO}_{3} \text { limited, } \mathrm{L} \\
\mathrm{NH}_{4} \text { limited, } \mathrm{L}\end{array}$ & $\begin{array}{l}\text { Carlucci et al. (1970) } \\
\text { Carlucci et al. }(1970) \\
\text { Collos (1982) } \\
\text { Collos }(1982)\end{array}$ \\
\hline $\begin{array}{l}\text { Thalassiosira pseudonana } \\
\text { 66-A } \\
3 \mathrm{H} \\
3 \mathrm{H}\end{array}$ & $\begin{array}{l}0.1-3.0 \\
0.5 \\
0.02-0.20 \\
0.09-0.48\end{array}$ & $\begin{array}{l}\mathrm{NO}_{3} \text { limited, } \mathrm{L} \\
\mathrm{NO}_{3} \text { limited, } \mathrm{L} \\
\mathrm{N} \text { sufficient, } \mathrm{L} \\
\mathrm{NO}\end{array}$ & $\begin{array}{l}\text { Kiefer et al. (1976) } \\
\text { Olson et al. (1980) } \\
\text { Sharp et al. (1979) } \\
\text { Parslow et al. (1984) }\end{array}$ \\
\hline
\end{tabular}

Nitrite uptake, again expressed as a percentage of nitrate uptake, can reach values which are much higher than nitrate uptake (up to 10 times). Note that these data are taken from experiments in which both nitrate and nitrite are present in the medium, so that interactions in uptake of those 2 nitrogen sources are involved. A variety of competition kinetics have been observed by different authors (Eppley \& Coatsworth 1968, Olson et al. 1980, Bilbao et al. 1981). Even though the high values of relative nitrite uptake are generally due to exhaustion of nitrate, they must be taken into account in the nitrogen budget.

In the field (Table 5), the range of values is similar, but here care must be taken due to the presence of bacteria which can also take up compounds such as nitrite. However, in the central northern North Pacific, Hattori \& Wada (1972) estimated that bacterial processes contributed to only a few percent of the observed nitrite uptake. Data from Olson (1981) for the Scotia Sea, Price et al. (1991) for the Equa- torial Pacific, and Slawyk \& Collos (1977) for the tropical Atlantic indicate a significant relationship between nitrite uptake and chlorophyll a. Moreover, the $y$ intercepts of those regression lines are not significantly dif-

Table 5. Nitrate and nitrite uptake by natural populations of marine phytoplankton. $U$ : uptake; L: light; D: dark; $I_{i}$ : surface irradiance

\begin{tabular}{|c|c|c|c|}
\hline Study area & $U_{\mathrm{NO}_{2}} / U_{\mathrm{NO}_{3}}$ & Conditions & Source \\
\hline Chesapeake Bay & $\begin{array}{l}0.01-8.0 \\
0.2-1.0 \\
0.15-3.3 \\
1.0-2.0 \\
0.12-0.53\end{array}$ & $\begin{array}{l}\text { Near surface, } L \\
\text { Near surface, } L \\
\text { Near surface, } L+D \\
\text { Near surface, } L+D \\
\text { Surface, } L\end{array}$ & $\begin{array}{l}\text { McCarthy et al. (1977) } \\
\text { McCarthy et al. (1984) } \\
\text { Glibert \& Garside (1992) } \\
\text { Bronk \& Glubert (1993) } \\
\text { Glibert et al. (1995) }\end{array}$ \\
\hline NW Africa & $0.1-2.0$ & $\mathrm{NO}_{3}$ added & Harrison \& Davis (1977) \\
\hline Tropical Atlantic & $\begin{array}{l}0.6 \\
3.5\end{array}$ & $\begin{array}{l}11 \mathrm{~h} \mathrm{D} \\
6 \mathrm{hL}\end{array}$ & $\begin{array}{l}\text { Slawyk \& Collos (1982) } \\
\text { Slawyk \& Collos (1982) }\end{array}$ \\
\hline North Pacific & $\begin{array}{l}0.13-0.30 \\
0.5-10 \\
0.5-2.4 \\
1.9\end{array}$ & $\begin{array}{l}24 \mathrm{~h} \text { profiles } \\
12 \mathrm{~h} \mathrm{~L} \text { profiles } \\
12 \mathrm{~h} \mathrm{D} \text { profiles } \\
5 \mathrm{~m}, 5.5 \mathrm{~h} \mathrm{~L}\end{array}$ & $\begin{array}{l}\text { Olson (1981) } \\
\text { Hattori \& Wada (1972) } \\
\text { Hattori \& Wada (1972) } \\
\text { Miyasaki et al. (1973) }\end{array}$ \\
\hline Equator. Pacific & $\begin{array}{l}0.05-0.16 \\
0.05-0.85 \\
0.14-1.79\end{array}$ & $\begin{array}{l}\text { Mixed layer } \\
\text { El Niño } \\
\text { Post El Niño }\end{array}$ & $\begin{array}{l}\text { Price et al. (1991) } \\
\text { McCarthy et al. (1996) } \\
\text { McCarthy et al. (1996) }\end{array}$ \\
\hline S. Calıfornia & $0.01-0.8$ & $24 \mathrm{~h}$ profiles & Olson (1981) \\
\hline Scotia Sea & $\begin{array}{l}0.004-0.01 \\
0.09-0.38 \\
0.02-0.28\end{array}$ & $\begin{array}{l}24 \text { h profiles } \\
\text { Surface, } \mathrm{L} \\
10 \% I_{0}, \mathrm{~L}\end{array}$ & $\begin{array}{l}\text { Olson (1981) } \\
\text { Olson et al. (1980) } \\
\text { Olson et al. }(1980)\end{array}$ \\
\hline
\end{tabular}


ferent from zero. While this does not preclude some uptake by bacteria, it suggests that it is mostly due to phytoplankton. Harris (1959) was probably the first to show that nitrite was a more important $\mathrm{N}$ source than nitrate for certain populations of marine phytoplankton, specially flagellates such as Peridinium (= Scrippsiella). Since then, studies on uptake of this compound have been surprisingly few, which is probably due to its low concentration in most surface waters. But Table 5 shows that its role in phytoplankton nutrition should not be neglected.

If not measured separately, nitrite uptake will lead to an overestimate of nitrate uptake when measured by the chemical method (nitrate disappearance). In the case of an isotopic method such as the ${ }^{15} \mathrm{~N}$ tracer technique ( $\mathrm{N}$ incorporation in the particulate matter), several cases must be considered. If nitrite is unlabelled, then its uptake should not affect estimates of nitrate uptake, provided the right equation is used (Collos 1987). If nitrite has the same isotopic composition as the initial labelled nitrate, then its uptake will overestimate nitrate uptake, but not new production, because this nitrite originated from nitrate in the first place and should be taken into account in new production estimates. Both situations are extreme and the

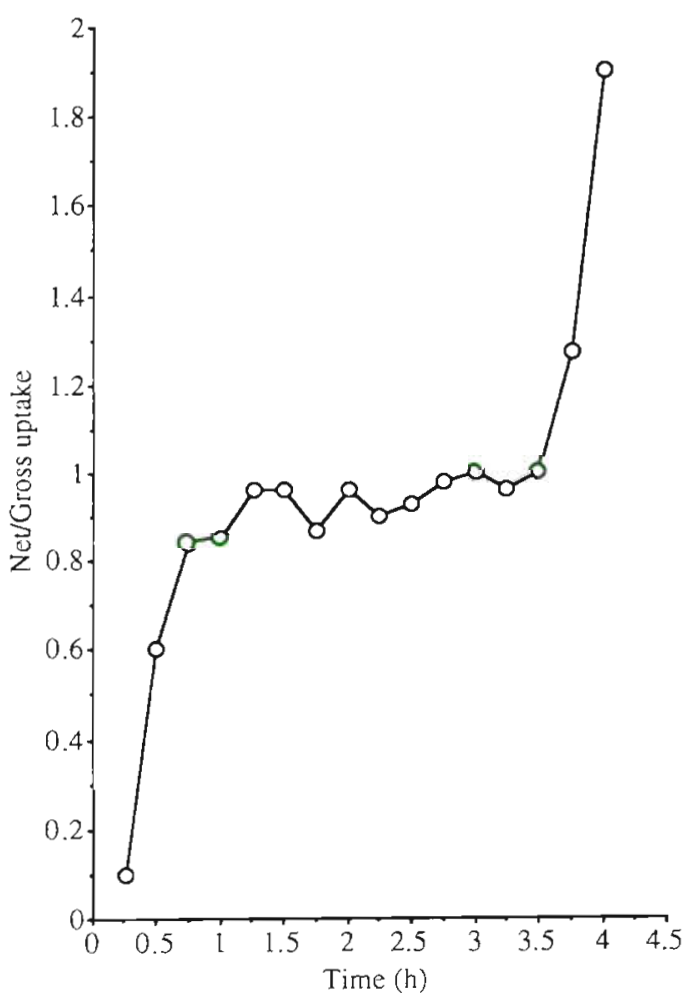

Fig. 2. Evolution of the net/gross nitrate uptake ratio by a $N$. limited Skeletonema costatum in a laboratory culture as a function of time. Nitrate addition $3 \mathrm{~h}$ after the beginning of the light period. Nitrite excretion occurs from time zero to $3.5 \mathrm{~h}$. Nitrite uptake occurs after 3.5 h. Data from Collos (1982)

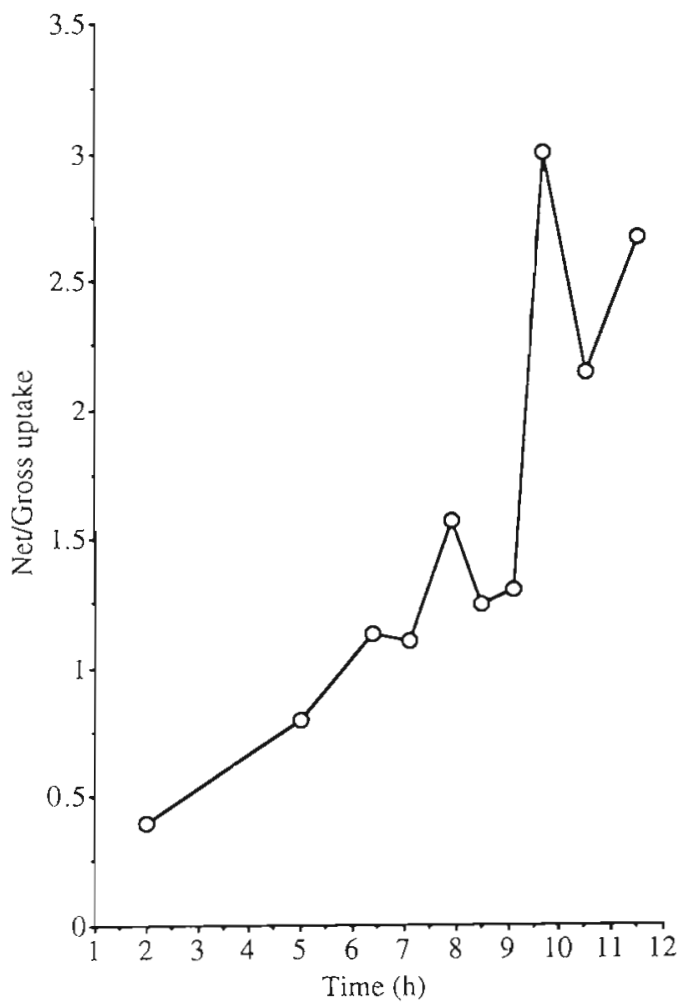

Fig. 3. Evolution of the net/gross nitrate uptake ratio by natural populations of marine phytoplankton in an upwelling area as a function of time. Nitrate addition at the beginning of the light period. Nitrite excretion occurs from time zero to $6 \mathrm{~h}$. Nitrite uptake occurs after $6 \mathrm{~h}$. Data from Harrison \& Davis (1977)

truth lies between the two as the isotopic composition of nitrite will be somewhere between the natural abundance and the ${ }^{15} \mathrm{~N}$ abundance of the initial labelled nitrate. This makes it difficult to estimate the bias involved, but it is probably negligible compared to that due to nitrite excretion. Again, the largest errors can be expected to be found in oligotrophic areas at low values of the $f$ ratio

During any incubation, both nitrite excretion and uptake can occur sequentially. Figs. $2 \& 3$ show the values taken by the ratio of net/gross uptake of nitrate as a function of time respectively for a laboratory culture of Skeletonema costatum (Collos 1982) and a natural population of marine phytoplankton in an upwelling area (Harrison \& Davis 1977). For both examples, during the first part of the incubation, when nitrite excretion occurs, the ratio takes on values smaller than 1, underestimating nitrate uptake. Conversely, towards the end of the incubation, when nitrite is taken up simultaneously with nitrate, the ratio of net/gross uptake takes on values greater than 1 . In both instances, the error can reach $100 \%$. This is valid for the nitrate uptake estimate by chemical methods 
(substrate disappearance) if nitrite is not measured separately, but the magnitude of the error involved during nitrite excretion should be the same for tracer methods $\left({ }^{15} \mathrm{~N}\right.$ isotope incorporation) because the ${ }^{15} \mathrm{~N}$ label coming originally from nitrate will be lost from the particulate matter as ${ }^{15} \mathrm{~N}$ nitrite is excreted.

\section{DISCUSSION}

The present review indicates that nitrite release by phytoplankton during nitrate uptake leads to underestimates of net nitrate uptake by chemical or isotopic methods in a significant way. The generally low internal nitrite concentrations found in phytoplankton seem to argue against any possible methodological problem such as cell rupture during filtration which is still a matter of controversy in measurements of dissolved organic nitrogen (DON) for example (Sharp 1977 , Aaronson 1978, Lancelot 1983). In extreme cases of very fragile planktonic organisms, vacuum filtration was shown to lead to large losses of particulate matter and 4 - to 5 -fold increases in DON, but no parallel increases in nitrite (Wilkerson \& Grunseich 1990), when compared to gravity filtration.

In comparison with the effect of DON release on net nitrate uptake (Bronk et al. 1994, Slawyk \& Raimbault 1995, Collos et al. 1996), the effect of nitrite excretion can be as great or even greater. It can be seen from Figs. 2 \& 3 that the net/gross ratio can reach values which are lower than those mentioned in Bronk et al. (1994) for a variety of environments. In addition, subsequent uptake of previously excreted nitrite will also affect estimates of net uptake in that the net/gross uptake ratio can take on values greater than 1 (up to 3.0 in the case of natural populations of marine phytoplankton in an upwelling area), thereby overestimating nitrate uptake.

The first phenomenon is likely to lead to bias in estimates of net nitrate uptake during both field and laboratory incubations. The magnitude of the bias will probably depend on the magnitude of the nitrate addition relative to the initial concentration. Concerning the second phenomenon, effects are more difficult to assess but are likely to be less serious for 2 reasons. First, any uptake of previously excreted nitrite will tend to compensate the effects of excretion. Secondly, field investigators generally try to avoid substrate exhaustion during their measurements, so that high ratios of relative nitrite uptake such as those shown in Tables 4 \& 5 should be rare. However, problems may arise in laboratory experiments when nitrate spikes are imposed on a nitrogen limited or a nitrogen starved culture and concentrations followed until substrate exhaustion is reached in order to estimate nitrate uptake kinetics from changes in concentrations (Collos 1982). In those situations, the patterns shown in Figs. 2 \& 3 fully apply.

In conclusion, it appears that nitrite excretion and uptake can influence net nitrate uptake estimates at least as much as DON release, and this should be taken into account in the experimental design of measurements of new production. This phenomenon is probably most important in stratified oceanic areas where intrusion of nitrate at the bottom of the euphotic zone will lead to perturbation of the nutrient regime and subsequent disequilibria in the assimilation pathway of the phytoplankton.

Acknowledgements. This paper is based on a lecture given on January 13, 1995 at the symposium 'Structure and dynamics of oligotrophic ecosystems: evolution of concepts' held at Villefranche-sur-Mer. The manuscript benefited from correspondence with M. Landry and P. E. Mihnea, as well as comments from 3 anonymous referees. This is a contribution from the APPA group (Dyfamed/France JGOFS program).

\section{LITERATURE CITED}

Aaronson S (1978) Excretion of organic matter by phytoplankton in vitro. Limnol Oceanogr 23:838

Anderson SM, Roels OA (1981) Effects of light intensity on nitrate and nitrite uptake and excretion by Chaetoceros curvisetus. Mar Biol 62:257-261

Bilbao M. Gabas JM. Serra JL (1981) Inhibition of nitrite uptake in the diatom Phaeodactylum tricornutum by nitrate, ammonium ions and some L-amino acids. Biochem Soc Trans 9:476-477

Bjørnsen PK (1988) Phytoplankton exudation of organic matter: why do healthy cells do it? Limnol Oceanogr 33: 151-154

Bronk DA, Glibert PM (1993) Application of a ${ }^{15} \mathrm{~N}$ tracer method to the study of dissolved organic nitrogen uptake during spring and summer in Chesapeake Bay. Mar Biol 115:501-508

Bronk DA, Glibert PM, Ward BB (1994) Nitrogen uptake, dissolved organic nitrogen release, and new production. Science 265: 1843-1846

Caperon J, Meyer J (1972) Nitrogen-limited growth of marine phytoplankton. I. Changes in population characteristics with steady-state growth rate. Deep-Sea Res 19:601-618

Carlucci AF, Hartwig EO, Bowes PM (1970) Biological production of nitrite in seawater. Mar Biol 7:161-166

Collos Y (1982) Transient situations in nitrate assimilation by marine diatoms. 2. Changes in nitrate and nitrite following a nitrate perturbation. Limnol Oceanogr 27:528-535

Collos $\mathrm{Y}(1987)$ Calculations of ${ }^{15} \mathrm{~N}$ uptake rates by phytoplankton assimilating one or several nitrogen sources. Appl Radiat Isot 38:275-282

Collos Y, Descolas-Gros C, Mornet F (1996) Diel variations in dissolved organic nitrogen in a coastal pond: relationships with carbon and nitrogen metabolism. J Exp Mar Biol Ecol 202:177-189

Collos Y, Slawyk G (1980) Nitrogen uptake and assimilation by marine phytoplankton. In: Falkowski P (ed) Primary productivity in the sea. Brookhaven Symposium in Biology No. 31, Plenum Press, New York, p 195-211

Collos Y, Slawyk G (1983) Ammonium and nitrate in the trop- 
ical and equatorial Atlantic: relations with the primary nitrite maximum. Mar Biol Lett 4:295-308

Conover SAM (1975) Partitioning of nitrogen and carbon in cultures of the marine diatom Thalassiosira fluviatilis supplied with nitrate, arnmonium, or urea. Mar Biol 32 $231-246$

Cresswell RC, Syrett PJ (1982) The uptake of nitrite by the diatom Phaeodactylum: interactions between nitrite and nitrate. J Exp Bot 33:1111-1121

Dore JE, Karl DM (1996) Nitrite distributions and dynamics at Station ALOHA. Deep-Sea Res 43:385-402

Dortch Q. Clayton JR Jr, Thoresen SS, Ahmed SI (1984) Species differences in accumulation of nitrogen pools in phytoplankton. Mar Biol 81:237-250

Dugdale RC (1977) Modeling. In: Goldberg ED, McCave IN O'Brien JJ, Steele JH (eds) The sea, Vol 6. Wiley-Interscience, New York, p 789-806

Dugdale RC, Goering JJ (1967) Uptake of new and regenerated forms of nitrogen in primary productivity. Limnol Oceanogr 12:196-206

Eppley RW, Coatsworth JL (1968) Uptake of nitrate and nitrite by Ditylum brightwellii-kinetics and mechanisms. I Phycol 4:151-156

Eppley RW, Peterson BJ (1979) Particulate organic matter flux and planktonic new production in the deep ocean. Nature 282:677-680

Epstein E (1972) Mineral nutrition of plants: principles and perspectives. J Wiley, New York

Flynn KJ, Flynn K (1998) Release of nitrite by marine dinoflagellates: development of a mathematical simulation. Mar Biol 130:455-470

Glibert PM, Conley DJ, Fisher TR, Harding LW Jr, Malone TC (1995) Dynamics of the 1990 winter/spring bloom in Chesapeake Bay. Mar Ecol Prog Ser 122:27-43

Glibert PM, Garside C (1992) Diel variability in nitrogenous nutrient uptake by phytoplankton in the Chesapeake Bay plume. J Plankton Res 14:271-288

Harris E (1959) The nitrogen cycle in Long Island Sound. Bull Bingham Oceanogr Collect 17:31-65

Harnson PJ, Davis CO (1977) Use of the perturbation technique to measure nutrient uptake rates of natural phytoplankton populations. Deep-Sea Res 24:247-255

Hattori A, Wada E (1972) Assimilation of inorganic nitrogen in the euphotic layer of the North Pacific Ocean. In: Takenouchi AY, Anraku M, Banse $K$, Kawamura T, Nishizawa S, Parsons TR, Tsujita T (eds) Biological oceanography of the Northern North Pacific Ocean. Idemitsu Shoten, Tokyo, p 279-287

Herbland A, Voituriez, B (1977) Production primaire, nitrate et nitrite dans l'Atlantique Tropical. I. Distribution du nutrate et production primaire. Cah ORSTOM Sér Oceanogr 15: $47-55$

Holligan PM, Pingree RD, Mardell GT (1985) Oceanic soljtons, nutrient pulses and phytoplankton growth. Nature 314:348-350

Kiefer DA, Olson RJ, Holm-Hansen O (1976) Another look at the nitrite and chlorophyll maxima in the central North Pacific. Deep-Sea Res 23:1199-1208

Klein P. Coste B (1984) Effects of wind-stress variability on nutrient transport into the mixed layer. Deep Sea Res 31. $21-37$

Lancelot C (1983) Factors affecting phytoplankton extracellular release in the Southern Bight of the North Sea. Mar Ecol Prog Ser 12:115-121

Laws EA, Wong DCL (1978) Studies of carbon and nitrogen metabolism by three marine phytoplankton species in nitrate-limited continuous culture. J Phycol 14:406-416
Losada M, Guerrero MG, Vega JM (1981) The assimilatory reduction of nitrate. In: Bothe $H$, Trebst $A$ (eds) Biology of inorganic nitrogen and sulfur. Springer-Verlag, Berlin. p 30-63

Lui NST, Roels OA (1972) Nitrogen metabolism of aquate organisms Il. The assimilation of nitrate, nitrite, and ammonia by Biddulphia aurita. J Phycol 8:259-264

Martinez R (1991) Transient nitrate uptake and assimilation in Skeletonema costatum cultures subject to nitrate starvation under low irradiance. J Plankton Res 13:499-512

McCarthy JJ, Garside C. Nevins JL, Barber RT (1996) New production along $140^{\circ} \mathrm{W}$ in the equatorial Pacific during and following the 1992 El Niño event. Deep-Sea Res 43:1065-1093

McCarthy JJ, Kaplan W, Nevins JL (1984) Chesapeake Bay nutrient and plankton dynamics. 2. Sources and sinks of nitrite. Limnol Oceanogr 29:84-98

McCarthy JJ, Taylor WR. Taft JL (1977) Nitrogenous nutrition of the plankton in the Chesapeake Bay. I. Nutrient availability and phytoplankton preferences. Limnol Oceanogr 22:996-1011

Mihnea PE, Voinescu I (1979) Utilization of the principal trophic anions by the marine unicellular algae as a function of the specific environmental conditions. Cercet Mar $12: 53-80$

Miyazaki T, Wada E, Hattori A (1973) Capacities of shallow waters of Sagami Bay for oxidation and reduction of inorganic nitrogen. Deep-Sea Res 20:571-577

Miyazaki T, Wada $E_{1}$ Hattori A (1975) Nitrite production from ammonia and nitrate in the euphotic layer of the western North Pacific Ocean. Mar Sci Communs 1:381-394

Newell SY, Fell JW. Statzell-Tallman A, Miller C, Cefalu R (1984) Carbon and nitrogen dynamics in decomposing leaves of three coastal marine vascular plants of the subtropics. Aquat Bot 19:183-192

Olson RJ (1981) ${ }^{15} \mathrm{~N}$ tracer studies of the primary nitrite maximum. J Mar Res 39:203-226

Olson RJ, SooHoo JB, Kiefer DA (1980) Steady-state growth of the marine diatom Thalassiosira pseudonana. Uncoupled kinetics of nitrate uptake and nitrite production. Plant Physiol 66:383-389

Parslow JS, Harrison PJ. Thompson PA (1984) Saturated uptake kinetics: transient response of the marine diatom Thalassiossira pseudonana to ammonium, nitrate, silicate or phosphate starvation. Mar Biol 83:51-59

Platt T, Harrison WG, Lewis MR, Li WKW, Sathyendranath S, Smith RE, Vezina AF (1989) Biological production of the oceans: the case for a consensus. Mar Ecol Prog Ser 52: $77-88$

Price NM, Andersen LF, Morel FMM (1991) Iron and nitrogen nutntion of equatorial Pacific plankton. Deep-Sea Res 38: $1361-1378$

Raimbault P (1986) Effect of temperature on nitrite excretion by three marine diatoms during nitrate uptake. Mar Biol 92:149-155

Sciandra A, Amara R (1994) Effects of nitrogen limitation on growth and nitrute excretion rates of the dinoflagellate Prorocentrum minimum. Mar Ecol Prog Ser 105:301-309

Serra JL, Llama MJ, Cadenas E (1978) Nitrate utilization by the diatom Skeletonema costatum. I. Kinetics of nitrate uptake. Plant Physiol 62:987-990

Sharp JH (1.977) Excretion of organic matter by marine phytoplankton: do healthy cells do it? Limnol Oceanogr 22: $381-399$

Sharp JH, Underhill PA, Hughes DJ (1979) Interaction (allelopathy) between marine diatoms: Thalassiosira pseudonana and Phaeodactylum tricornutum. J Phycol 15:353-362 
Slawyk G, Collos Y (1977) Assimilation de divers composés de l'azote. In: Coste B (ed) Campagne GUIDOME 1976. Publ CNEXO, série Résultats des campagnes à la mer, 13(2): $21-24$

Slawyk G, Collos Y $(1982){ }^{13} \mathrm{C}$ and ${ }^{15} \mathrm{~N}$ uptake by marine phytoplankton. 2. Results from a tropical area. Rapp PV Réun Cons Int Explor Mer 180:209-213

Slawyk G, Raimbault P (1995) Simple procedure for simultaneous recovery of dissolved inorganic and organic nitrogen in ${ }^{15} \mathrm{~N}$-tracer experiments and improving the isotopic mass balance. Mar Ecol Prog Ser 124:289-299

Thoresen SS, Dortch Q, Ahmed SI (1982) Comparison of methods for extracting intracellular pools of inorganic nitrogen from marine phytoplankton. J Plankton Res 4 : $695-704$

Vaccaro RF (1965) Inorganic nitrogen in sea water. In: Riley JP, Skirrow G (eds) Chemical oceanography. Academic

Editorial responsibility: Otto Kinne (Editor),

Oldendorf/Luhe, Germany
Press, New York, p 365-408

Vaccaro RF, Ryther JH (1960) Marine phytoplankton and the distribution of nitrite in the sea. J Cons Int Explor Mer 25:260-271

Voituriez B, Herbland A (1977) Production primaire, nitrate et nitrite dans l'Atlantique tropical. II. Distribution du nitrate et production du nitrite. Cah ORSTOM Sér Océanogr 15: $57-65$

Wada E, Hattori A (1971) Nitrite metabolism in the euphotic layer of the central North Pacific ocean. Limnol Oceanogr $16: 766-772$

Wilkerson FP, Grunseich G (1990) Formation of blooms by the symbiotic ciliate Mesodinum rubrum: the significance of nitrogen uptake. J Plankton Res 12:973-989

ZoBell CE (1935) The assimilation of ammonium nitrogen by Nitzschia closterium and other marine phytoplankton. Proc Natl Acad Sci 21:517-522

Submitted: March 30, 1998; Accepted: July 8, 1998 Proofs received from author(s): September 7, 1998 